Int. J. Odontostomat., 9(3):505-510, 2015.

\title{
Ex vivo Effect of Copper Sulfate on Enterococcus faecalis in Root Canals
}

\author{
Efecto ex vivo del Sulfato de Cobre sobre \\ Enterococcus faecalis en Canales Radiculares
}

\author{
Gabriela Sánchez-Sanhueza*; Raúl Alcántara-Dufeu*; Lorena Carrillo*; \\ Hedring Mansilla**; Camila Novoa** \& Helia Bello-Toledo ${ }^{* * *}$
}

SÁNCHEZ-SANHUEZA, G.; ALCÁNTARA-DUFEU, R.; CARRILLO, L.; MANSILLA, H.; NOVOA, C.\& BELLO-TOLEDO, H. Ex vivo effect of copper sulfate on Enterococcus faecalis in root canal. Int. J. Odontostomat., 9(3):505-510, 2015.

\begin{abstract}
The incomplete disinfection of root canal system has been reported as the main cause of post-treatment disease, due to the persistence of bacteria. For over thirty years Enterococcus faecalis has been considered the most common bacterial species isolated from persistent root canal infections, resisting antibacterial agents, such as chlorhexidine and calcium hydroxide. Several studies have indicated that copper has optimal disinfecting capacities in a hospital environment. Aimed to know the ex vivo effect of copper sulfate $\left(\mathrm{CuSO}_{4}\right)$ on $\mathrm{E}$. faecalis. Thirty-six extracted human tooth root canals were inoculated with E. faecalis ATCC 29212. These root canals had undergone endondontic procedures with a rotatory system. The effect of $\mathrm{CuSO}_{4}$ was determined by plate count method of $E$. faecalis obtained from one sample of each tooth under three incubation times ( $4^{\text {th }}, 7^{\text {th }}$ and $10^{\text {th }}$ day). The canals medicated with $\mathrm{CuSO}_{4}$, the bacterial count decreased 6 log after 4 days and remained as such without statistically significant change until the tenth day. It is an indisputable fact of its antibacterial action. The bacterial persistence may be due to the ability of $E$. faecalis to remain viable in root canals up to 12 months without additional nutrients. These preliminary results could be used for further scientific work assessing the potential for the use of cooper in dentistry.
\end{abstract}

KEY WORDS: copper sulfate, Enterococcus faecalis, bacterial load, endodontics.

\section{INTRODUCTION}

Incomplete disinfection of root canals is the major cause of post-treatment reinfection (Ran et al., 2015). On the other hand, it has been reported that bacteria can survive inside the canal even after a careful chemo-mechanical preparation (Hohscheidt et al., 2013). Against this and given the fact that Enterococcus faecalis is one of the most commonly isolated bacteria from the root canals of teeth with apical persistence periodontitis (Arias-Moliz et al., 2010; Kumar, 2013) this bacterial specie has been used as the gold standard when assessing the residual effectiveness of irrigating agents such as sodium hypochlorite $(\mathrm{NaOCl})$ and chlorhexidine $(\mathrm{CHX})$ (AriasMoliz et al.; Delgado et al., 2010) chelating agents such as ethylenediaminetetraacetic acid (EDTA) or cationic detergents such as cetrimide (Baca et al., 2011), but conclusive and significant results have not been thus far obtained.

Regarding intracanal medication with calcium hydroxide $\left[\mathrm{Ca}(\mathrm{OH})_{2}\right]$ pastes (Lima et al., 2012) in several formulations, E. faecalis has proved to be the most resistant bacteria, compared to anaerobic gramnegative bacteria (Burley \& Sedgley, 2012; Evans et al., 2002; Delgado et al.).

By searching for a new agent different from those widely used to date in dentistry that could aid in the elimination of resistant strains of bacteria such as $E$. faecalis, $\mathrm{CuSO}_{4}$ appeared as a suitable candidate, as

\footnotetext{
* Assistant Professor Department of Restorative Dentistry, Faculty of Dentistry, Universidad de Concepción, Concepción, Chile. * Student, Specialization in Endodontics, Faculty of Dentistry, Universidad de Concepción, Concepción, Chile.

${ }^{* * *}$ Associate Professor. Research Laboratory of Antibacterial Agents, Department of Microbiology, Faculty of Biological Sciences, Universidad de Concepción, Concepción, Chile.
} 
this compound has been shown to have optimal properties regarding disinfection within the inpatient hospital environment (Gould et al., 2009; O'Gorman \& Humphreys, 2012). The mechanism of action of ionic copper $\left(\mathrm{CuSO}_{4}\right)$ is primarily based on the ability of the copper to yield and capturing electrons, enabling the generation of radical oxygen species (ROS), which in turn can lead to increased production of hydroxyl toxic radicals (Gould et al.; Grass et al., 2011). A study compared the drugs commonly used in endodontics and copper sulfate pentahydrate that presented antimicrobial activity at low concentrations, being slightly higher than the chlorhexidine (Sierra et al., 2013).

The present study aim to assess the ex vivo effect of $\mathrm{CuSO}_{4}$ on the bacterial load in the root canals of human teeth contaminated with $E$. faecalis. This pathogen is frequently isolated from teeth with a history of endodontic therapy failure (Evans et al.; Delgado et al.; Lima et al.).

\section{MATERIAL AND METHOD}

An ex vivo, longitudinal experimental and retrospective study was carried out. It was approved by the Bioethical Committee of the Faculty of Dentistry at the Universidad de Concepcion, Chile (C.I.Y.B. N ${ }^{\circ}$ 06/14). Forty teeth were selected following the inclusion criteria: The roots should come from teeth extracted for periodontal or orthodontic reasons and remain stored in saline solution; the roots canals should be anatomically classified as type I according to Weine's, possessing slight curvatures only (lower than $20^{\circ}$ ) according to Schneider (1971) and displaying a full apical closing, as well as being clinically permeable. Teeth that despite having the characteristics mentioned above, presented cavities or filings on their surface were excluded. In order to check the number and type of canals of the teeth root, a digital radiographic analysis of each collected tooth was carried out using a Vista Scan Mini ${ }^{\circledR}$ (Dürr Dental, Bietigheim-Bissingen, Germany) plate scanner.

Preparation of roots. Bone, soft tissue and calculus were removed from the surface of each of the 40 selected roots. Root length was standardized to $16 \mathrm{~mm}$ with a rotating diamond saw (Brasseler USA, Savannah, GA, USA). A chemo-mechanical preparation was performed, irrigating with $3 \mathrm{ml}$ of $5.25 \%$ $\mathrm{NaOCl}$ applied to the root canals with Monoject ${ }^{\circledR}$
(Kendall, Mansfield, MA, USA) 27G syringes. Canals were permeabilized with $\mathrm{K} \# 10$ or \#15 files (DentsplyMaillefer, Ballaigues, Switzerland) as appropriate, until a K\#20 file (Dentsply-Maillefer Ballaigues, Switzerland) was needed, up to a working length of $15 \mathrm{~mm}$. Root canals were prepared to the above mentioned working length, with Pro Taper Universal ${ }^{\circledR}$ (Dentsply-Maillefer, Ballaigues, Switzerland) (Javidi et al., 2014) SX to F2 mechanized instrumentation, according to the manufacturer's instructions. Smear layer removal was achieved by incubation in $10 \%$ (w/v) EDTA with sonic activation using the Endo activator ${ }^{\circledR}$ (Dentsply-Maillefer, Ballaigues, Switzerland) for one minute. A final irrigation with $5.25 \% \mathrm{NaOCl}$ was performed, also under sonic activation, refilling the solution every $20 \mathrm{~s}$, a total of three times, followed by rinsing with $5 \mathrm{ml}$ of sterile saline. Canals were dried with sterile paper cones. Subsequently, the dried external root surface was covered with 2 thin layers of composite $X$ Flow $^{\circledR}$ (Dentsply-Maillefer, Ballaigues, Switzerland), except on the coronal access. Each root canal was placed in a $15 \mathrm{ml}$ centrifuge tube (Biologix Plastics Co., Jiangsu, China) with $5 \mathrm{ml}$ of phosphate buffered saline (PBS) (Sigma-Aldrich, St. Louis, MO, USA). Then, samples were autoclaved for $14 \mathrm{~min}$ at $121^{\circ} \mathrm{C}$. A sterility control was carried out by randomly selecting 2 sterilized roots canals: for this $100 \mu \mathrm{l}$ of each sample was plated onto KF agar plates (Merck, D-61 Darmstadt, Germany), to select Enterococcus spp. Plates were incubated aerobically at $37^{\circ} \mathrm{C}$ for $24 \mathrm{~h}$. The absence of bacterial growth corroborated a successful sterilization process (Atila-Pektas et al., 2013; Pavaskar et al., 2012).

Inoculation of roots. For the inoculation of root canals, E. faecalis ATCC 29212 was used (Valera et al., 2009). After $24 \mathrm{~h}$ of incubation, a bacterial suspension adjusted to turbidity $0.5 \mathrm{McF}$ arland was prepared from the logarithmic phase of bacterial growth, in order to standardize the inoculum. The procedure of root canal inoculation with $E$. faecalis was carried out under aseptic conditions with sterile gloves, using a laminar flow cabinet (Thermo Scientific ${ }^{\circledR}$, Marietta, Ohio, USA).

The previously prepared sterile roots were removed from PBS and were each placed in $5.0 \mathrm{ml}$ of $0.5 \mathrm{McF}$ arland bacterial suspensions, and incubated at $37^{\circ} \mathrm{C}$ for seven days under aerobic conditions.

In order to verify both bacterial viability and the purity of the inoculum, after finishing the seven day incubation, a $10 \mu \mathrm{l}$ aliquot of the bacterial suspension from two randomly selected 4 samples was collected 
and seeded in 5\% (w/v) Trypticase Soy Agar (TSA) (Difco, Detroit, MI, USA), the plates were incubated aerobically at $37^{\circ} \mathrm{C}$ for 2 days. Following the incubation period the plates were visually inspected to insure that only one type of colony morphology was visible, an indication that the bacterial inoculum was not contaminated by non- Enterococcus microorganisms. Furthermore biochemical tests like growth in $6.5 \% \mathrm{NaCl}$ broth, esculin hydrolysis in the presence of bile salts and arabinose fermentation test were performed in order to ensure inoculum purity (Javidi et al.).

Intracanal treatment of the roots canals. At the end of the incubation period, the roots were removed from the tubes and washed three times with $5 \mathrm{ml}$ of sterile saline both inside and outside the root canal. Subsequently, samples were transferred into Eppendorf micro tubes.

Thirty-six remaining roots were randomly divided into one experimental group of 10 roots medicated intracanally with $\mathrm{CuSO}_{4}$ ( Merck $^{\circledR}$, Darmstadt, Germany) pulverized with propylene glycol at a concentration of $10 \mathrm{~g} / \mathrm{ml}$ (10:1), one group with three roots incubated in sterile saline as negative control group and one positive control group composed by three roots medicated $1 \%$ Chlorhexidine gel Oralgene ${ }^{\circledR}$ (Maver, Lampa, Chile). Each one of the intracanal treatments was introduced into the root canals using a K\# 25 sterile file (DentsplyMaillefer ${ }^{\circledR}$, Ballaigues, Switzerland) and sterile cotton. Sterile cotton and a temporary filling material Fermin ${ }^{\circledR}$ (Detax, Ettlingen, Germany) were placed at the opening of each canal as a seal. Each experimental group was incubated for 4,5 and 10 days at $37^{\circ} \mathrm{C}$ (Awawdeh et al., 2009).

Bacterial sampling from root canals. Samples from each experimental group were taken at the three incubation time points. Both the temporary seal and the cotton were removed with a \#71/72 cavity curette (Dentsply-Maillefer ${ }^{\circledR}$, Ballaigues, Switzerland) and a straight probe (Dentsply-Maillefer ${ }^{\circledR}$, Ballaigues, Switzerland). The intracanal treatment was removed with a sterile $\mathrm{K} \# 25$ file and the canal was irrigated with $5 \mathrm{ml}$ of sterile saline using a disposable syringe (Cranberry ${ }^{\circledR}$ ).

The content of the root canal was absorbed into a sterile paper tip. Each paper tip was maintained in position inside the canal at the established working length for $1 \mathrm{~min}$ and then transferred into a microtube containing $1 \mathrm{ml}$ of Tryptic Soy Broth (TSB) (Difco, Detroit, MI). In addition, samples of dentine from each dental root were taken using H\#35 files (DentsplyMaillefer ${ }^{\circledR}$, Ballaigues, Switzerland) at working length and placed into a microtube containing $1 \mathrm{ml}$ of TBS (Difco, Detroit, MI, USA) (Awawdeh et al., 2008). From each sample, the bacterial count was performed on TSA (Difco, Detroit, MI, USA) plates followed by a twoday incubation at $37^{\circ} \mathrm{C}$ (Naghili et al., 2013).

Statistical analysis. Data were entered into Microsoft Excel sheets for analysis. Nonparametric tests (Kruskal-Wallis ANOVA) were performed. Multiple comparisons were performed with Games-Howell test to corroborate the differences. To get a significant $p$ value $<0.05$ was considered difference. SPSS software (SPSS, Chicago, USA, version 22) was used (AtilaPektas et al.; Pavaskar et al.).

\section{RESULTS}

A representation of the temporal progression of the counts of $E$. faecalis isolated from roots canals treated with $\mathrm{CuSO}_{4}$ is presented in Table I. It can be seen that the initial count in log 10 values $\left(10^{8}\right)$ decreased after 4 days of treatment with $\mathrm{CuSO}_{4}$ (2.17 \pm 1.72$)$, indicating a reduction of 6 log. However, subsequent counts ( 7 and 10 days) did not vary significantly (Games-Howell test, $\mathrm{p}>0.05$ ). Finally, $E$. faecalis CFU mean values (Log values) from the root canals treated with copper sulfate at $0,4,7$ and 10 days were compared to each other using the noparametric Kruskal-Wallis statistical test (Atila-Pektas

Table I. CFU means (Log values) in root canals treated with copper sulfate for 0, 4, 7 and 10 days.

\begin{tabular}{ccccccc}
\hline Day & Samples & Mean & SD & Median & Mean Rank & p (Kruskal-Wallis) \\
\hline $\mathbf{0}$ & 10 & 8 & 0 & 8 & $35.50 \mathrm{~A}$ & \\
$\mathbf{4}$ & 10 & 2.17 & 1.72 & 2.85 & $13.90 \mathrm{~B}$ & $<0.0001$ \\
$\mathbf{7}$ & 10 & 2.49 & 1.52 & 3.06 & $16.25 \mathrm{~B}$ & \\
$\mathbf{1 0}$ & 10 & 2.48 & 2.22 & 3.15 & $16.35 \mathrm{~B}$ & \\
\hline
\end{tabular}

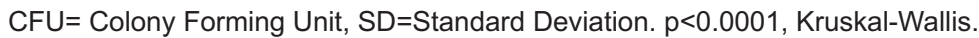

Means with the same letter are not significantly different $(p>0.05)$. 
et al.; Pavaskar et al.). The performed analysis indicated that the differences between the counts of $E$. faecalis obtained after 4, 7 and 10 days of intracanal copper sulfate treatment are statistically significant $(p<0.0001)$.

\section{DISCUSSION}

Copper has been shown to have an important antimicrobial effect (Prado et al., 2012), as it produces death on contact (Gould et al.; Grass et al.). The effectiveness of $\mathrm{Cu}$ alloys, in reducing the bacterial load, has been tested in various studies both in vitro and clinically (Souli et al.). In addition, maintaining the intracellular homeostasis of metallic ions is crucial to the survival of $E$. faecalis (Abrantes et al., 2011). Therefore, its use should be assessed at shorter intervals of time in order to avoid the appearance of resistant strains, considering its use has not been reported to date in endodontics (Sierra et al.).

E. faecalis was selected in this study because it is a pathogen frequently isolated from persisting endodontic infections (Stuart et al., 2006), due to the resistance of this bacteria to intracanal agents such as $\mathrm{Ca}(\mathrm{OH})_{2}$ (Evans et al.) and also its capacity of surviving extreme conditions (Stuart et al.; Wang et al., 2012). Although the experimental model used in this study is similar to other studies (Atila-Pektas et al.; Javidi et al.), there were no ex vivo reports about $\mathrm{CuSO}_{4}$ to date. Therefore the exploratory nature of the present work regarding the effect of this antibacterial in human dental root canals is significant.

The possible causes of the persistent counts may be due to the capacity of $E$. faecalis of maintaining its viability in root canals up to 12 months without additional nutrients (Evans et al.; Ran et al.; van der Waal et al., 2012). The selective advantage of a subset of the population resistant to the antimicrobial agent used appears to be an important factor in the results obtained in the present work, and we believe it may play an important role in the development of chronic apical periodontitis (Wang et al.). Alternatively, this may be due to the inability of the medication to reach the apical third and penetrate the dental tubules where $E$. faecalis is capable of settling (Javidi et al.). The persistence of $E$. faecalis has been previously observed at $72 \mathrm{~h}, 8$ and 14 days, when $E$. faecalis was treated with other medications, reinforcing the idea of its great capacity of persisting after treatment (Özok et al.,
2012), possibly as a result of its resistance genes (Burley \& Sedgley; Souli et al., 2013). Considering the value of the initial inoculum of $108 \mathrm{CFU} / \mathrm{ml}$, there was a decrease of inoculum from day 0 to day 4 with significant difference. This point reinforces the idea that a short time of efficient medication such a copper may decrease the probability of a selection resistant strains.

It is important to take into account that the sample was obtained from filed dentinal walls of the root canals using $\mathrm{H}$ files and sterile paper tips. This method has also been used in studies by Awawdeh et al. One of the drawbacks of the present work was the impossibility of standardizing the quantities of filed material obtained from each root. It has been previously described that the use of paper cones has limitations at the time of assessing the effectiveness in obtaining a significant sample of the root canal content (Özok et al.). This point needs more attention in further investigation. Finally, the inclusion a model multispecies biofilm it could be considered in future experiments.

However, the initial count in log 10 values $\left(10^{8}\right)$ decreased after 4 days of treatment with $\mathrm{CuSO}_{4}$ $(2.17 \pm 1.72)$, indicating a reduction of $6 \log$ is an unquestionable fact of its antibacterial action.

\section{CONCLUSIONS}

The ex vivo effect of copper sulfate on $E$. faecalis was observed after 4 days of intracanal application, results that reinforce its use as an antimicrobial.

The preliminary results obtained from this study make it necessary to continue generating further ex vivo and in vivo scientific studies in order to generate further evidence about the viability of using copper sulfate in dentistry in the future, emphasizing the comparison of $\mathrm{CuSO}_{4}$ with antimicrobials commonly used in endodontics. As a projection, it would be of interest to assess the genetic platform present in the resistant strains of $E$. faecalis following the application of medication containing copper sulfate.

ACKNOWLEDGMENTS. The Research Laboratory of Antibacterial Agents of the Faculty of Biological Sciences of the University of Concepción and Scholarship (CONICYT-PCHA/ Doctorado Nacional /2013 folio 21130022), for PhD in Sciences, Mention Microbiology, University of Concepcion, for their support. 
SÁNCHEZ-SANHUEZA, G.; ALCÁNTARA-DUFEU, R.; CARRILLO, L.; MANSILLA, H.; NOVOA, C.\& BELLO-TOLEDO, H. Efecto ex vivo del sulfato de cobre sobre Enterococcus faecalis en canales radiculares. Int. J. Odontostomat., 9(3):505510, 2015.

RESUMEN: La desinfección incompleta del sistema de canales radiculares ha sido reportada como la principal causa de infección post tratamiento, debido a la persistencia bacteriana. Por más de 30 años, Enterococcus faecalis se ha considerado una de las especies bacterianas más comunes aisladas de infecciones persistentes del canal radicular, resistiendo a agentes antibacterianos, como clorhexidina e hidróxido de calcio. Varios estudios han indicado que el cobre tiene una capacidad de desinfección óptima en un entorno hospitalario. Con el objetivo de conocer el efecto ex vivo de sulfato de cobre $\left(\mathrm{CuSO}_{4}\right)$ sobre $E$. faecalis. Treinta y seis canales radiculares de dientes humanos extraídos fueron inoculados con $E$. faecalis ATCC 29212. Estos canales radiculares fueron previamente sometidos a instrumentación con un sistema de rotación. El efecto de $\mathrm{CuSO}_{4}$ se determinó por el método de recuento en placa de $E$. faecalis a partir de una muestra de cada diente en tres tiempos de incubación (4, 7 y 10 días). En los canales medicados con $\mathrm{CuSO}_{4}$, el recuento de bacterias se redujo 6 log después de 4 días y se mantuvo como tal sin cambio estadísticamente significativo hasta el día 10 . Esto demuestra su poder antibacteriano. La persistencia bacteriana pudo ser deberse a la capacidad de E. faecalis para seguir siendo viable en canales hasta 12 meses sin nutrientes adicionales. Estos resultados preliminares podrían ser utilizados para otros trabajos científicos que evaluen el potencial uso de cobre en odontología.

PALABRAS CLAVE: sulfato de cobre, Enterococcus faecalis, carga bacteriana, endodoncia.

\section{REFERENCES}

Abrantes, M. C.; Lopes, Mde. F. \& Kok, J. Impact of manganese, copper and zinc ions on the transcriptome of the nosocomial pathogen Enterococcus faecalis V583. PLoS One, 6(10):e26519, 2011.

Arias-Moliz, M. T.; Ferrer-Luque, C. M.; González-Rodríguez, M. P.; Valderrama, M. J. \& Baca, P. Eradication of Enterococcus faecalis biofilms by cetrimide and chlorhexidine. J. Endod., 36(1):87-90, 2010.

Atila-Pektas, B.; Yurdakul, P.; Gülmez, D. \& Görduysus, O. Antimicrobial effects of root canal medicaments against Enterococcus faecalis and Streptococcus mutans. Int. Endod. J., 46(5):413-8, 2013.

Awawdeh, L.; Al-Beitawi, M. \& Hammad, M. Effectiveness of propolis and calcium hydroxide as a short-term intracanal medicament against Enterococcus faecalis: a laboratory study. Aust. Endod. J., 35(2):52-8, 2009.

Baca, P.; Mendoza-Llamas, M. L.; Arias-Moliz, M. T.; González-Rodríguez, M. P. \& Ferrer-Luque, C. M. Residual effectiveness of final irrigation regimens on Enteroccus faecalis-infected root canals. J. Endod., 37(8):1121-3, 2011.

Burley, K. M. \& Sedgley, C. M. CRISPR-Cas, a prokaryotic adaptive immune system, in endodontic, oral, and multidrug-resistant hospital-acquired Enterococcus faecalis. J. Endod., 38(11):1511-5, 2012.

Delgado, R. J.; Gasparoto, T. H.; Sipert, C. R.; Pinheiro, C. R.; Moraes, I. G.; Garcia, R. B.; Bramante, C. M.;
Campanelli, A. P. \& Bernardineli, N. Antimicrobial effects of calcium hydroxide and chlorhexidine on Enterococcus faecalis. J. Endod., 36(8):1389-93, 2010.

Evans, M.; Davies, J. K.; Sundqvist, G. \& Figdor, D. Mechanisms involved in the resistance of Enterococcus faecalis to calcium hydroxide. Int. Endod. J., 35(3):2218, 2002.

Gould, S. W. J.; Fielder, M. D.; Kelly, A. F.; Morgan, M.; Kenny, J. \& Naughton, D. P. The antimicrobial properties of copper surfaces against a range of important nosocomial pathogens. Ann. Microbiol., 59(1):151-6, 2009.

Grass, G.; Rensing, C. \& Solioz, M. Metallic copper as an antimicrobial surface. Appl. Environ. Microbiol., 77(5):1541-7, 2011.

Hohscheidt, G. L.; Böttcher, D. E.; Fatturi Parolo, C. C.; Montagner, F. \& Grecca, F. S. Response of E. faecalis biofilms to different associations of auxiliary substances during root canal preparation: a confocal laser microscopy analysis. Microsc. Res. Tech., 76(6):658-62, 2013.

Javidi, M.; Afkhami, F.; Zarei, M.; Ghazvini, K. \& Rajabi, O. Efficacy of a combined nanoparticulate/calcium hydroxide root canal medication on elimination of Enterococcus faecalis. Aust. Endod. J., 40(2):61-5, 2014.

Kumar, $\mathrm{H}$. An in vitro evaluation of the antimicrobial efficacy of Curcuma longa, Tachyspermum ammi, chlorhexidine gluconate, and calcium hydroxide on Enterococcus faecalis. J. Conserv. Dent., 16(2):144-7, 2013. 
SÁNCHEZ-SANHUEZA, G.; ALCÁNTARA-DUFEU, R.; CARRILLO, L.; MANSILLA, H.; NOVOA, C.\& BELLO-TOLEDO, H. Ex vivo effect of copper sulfate on Enterococcus faecalis in root canal. Int. J. Odontostomat., 9(3):505-510, 2015.

Lima, R. K.; Guerreiro-Tanomaru, J. M.; Faria-Júnior, N. B. \& Tanomaru-Filho, M. Effectiveness of calcium hydroxidebased intracanal medicaments against Enterococcus faecalis. Int. Endod. J., 45(4):311-6, 2012.

Naghili, H.; Tajik, H.; Mardani, K.; Razavi Rouhani, S. M.; Ehsani, A. \& Zare, P. Validation of drop plate technique for bacterial enumeration by parametric and nonparametric tests. Vet. Res. Forum, 4(3):179-83, 2013.

O'Gorman, J. \& Humphreys, H. Application of copper to prevent and control infection. Where are we now? J. Hosp. Infect., 81(4):217-23, 2012.

Ozok, A. R.; Persoon, I. F.; Huse, S. M.; Keijser, B. J.; Wesselink, P. R.; Crielaard, W. \& Zaura, E. Ecology of the microbiome of the infected root canal system: a comparison between apical and coronal root segments. Int. Endod. J., 45(6):530-41, 2012.

Pavaskar, R.; de Ataide, Ide. N.; Chalakkal, P.; Pinto, M. J.; Fernandes, K. S.; Keny, R. V. \& Kamath, A. An in vitro study comparing the intracanal effectiveness of calcium hydroxide- and linezolid-based medicaments against Enterococcus faecalis. J. Endod., 38(1):95-100, 2012.

Prado, J. V.; Vidal, A. R. \& Durán, T. C. Application of copper bactericidal properties in medical practice. Rev. Med. Chil., 140(10):1325-32, 2012.

Ran, S.; Wang, J.; Jiang, W.; Zhu, C. \& Liang, J. Assessment of dentinal tubule invasion capacity of Enterococcus faecalis under stress conditions ex vivo. Int. Endod. J., 48(4):362-72, 2015.

Schneider, S. W. A comparison of canal preparations in straight and curved root canals. Oral Surg. Oral Med. Oral Pathol., 32(2):271-5, 1971.

Sierra, M.; Sanhueza, A.; Alcántara, R. \& Sánchez, G. Antimicrobial evaluation of copper sulfate (II) on strains of Enterococcus faecalis. In vitro study. J. Oral Res., 2(3):114-8, 2013.

Souli, M.; Galani, I.; Plachouras, D.; Panagea, T.: Armaganidis, A.; Petrikkos, G. \& Giamarellou, H. Antimicrobial activity of copper surfaces against carbapenemase-producing contemporary Gram-negative clinical isolates. J. Antimicrob. Chemother., 68(4):852-7, 2013.

Stuart, C. H.; Schwartz, S. A.; Beeson, T. J. \& Owatz, C. B. Enterococcus faecalis: its role in root canal treatment failure and current concepts in retreatment. J. Endod., 32(2):93-8, 2006.

Valera, M. C.; Silva, K. C.; Maekawa, L. E.; Carvalho, C. A.; Koga-Ito, C. Y.; Camargo, C. H. \& Lima, R. S.
Antimicrobial activity of sodium hypochlorite associated with intracanal medication for Candida albicans and Enterococcus faecalis inoculated in root canals. J. Appl. Oral Sci., 17(6):555-9, 2009.

van der Waal, S. V.; Jiang, L. M.; de Soet, J. J.; van der Sluis, L. W.; Wesselink, P. R. \& Crielaard, W. Sodium chloride and potassium sorbate: a synergistic combination against Enterococcus faecalis biofilms: an in vitro study. Eur. J. Oral Sci., 120(5):452-7, 2012.

Wang, Q. Q.; Zhang, C. F.; Chu, C. H. \& Zhu, X. F. Prevalence of Enterococcus faecalis in saliva and filled root canals of teeth associated with apical periodontitis. Int. J. Oral Sci.,4(1):19-23, 2012.

Correspondence to:

Helia Bello-Toledo. M.Sc; PhD.Sc.

Laboratorio de Investigación en Agentes Antibacterianos

Departamento de Microbiología

Facultad de Ciencias Biológicas

Universidad de Concepción

Concepción

CHILE

Email: hbello@udec.cl

Received: 15-09-2015

Accepted: 27-10-2015 